\title{
PENERAPAN BIOLOGI TERAPAN OLEH SISWA SMP DI KABUPATEN TABANAN
}

\author{
I Ketut Surata, I Gede Sudirgayasa, I Made Sudiana, \\ I Gst Agung Ayu Nova Dwi Marhaeni \\ Program Studi Pendidikan Biologi, Fakultas Pendidikan MIPA \\ IKIP Saraswati Tabanan \\ Email : igedesudirgayasa@gmail.com
}

\begin{abstract}
ABSTRAK
Penelitian ini bertujuan untuk mengetahui penerapan biologi terapan dalam kehidupan sehari-hari oleh siswa sekolah menengah pertama di Kabupaten Tabanan Provinsi Bali. Metode yang digunakan dalam penelitian ini adalah metode penelitian survei. Responden yang menjadi subjek dalam penelitian ini adalah siswa kelas VIII dari 3 sekolah sampel di Kabupaten Tabanan. Adapun ketiga sekolah sampel tersebut adalah SMP Negeri 2 Tabanan, SMP Negeri 1 Kerambitan, SMP Negeri 2 Penebel. Pengumpulan data dilakukan dengan penyebaran kuesioner kepada responden. Kuesioner terdiri dari 25 item pertanyaan. Data yang terkumpul dianalisis secara deskriptif dengan penyajian berupa uraian lengkap yang dilengkapi data visual berupa tabel dan grafik. Masing-masing item pertanyaan diberikan rentangan skor 0 sampai 5 . Skor minimal adalah 0, sedangkan skor maksimal adalah 5. Skor total masing-masing siswa nantinya dikonversi kedalam skala 100. Selanjutnya ditentukan nilai-rata-rata untuk masingmasing sekolah sampel. Nilai rata-rata siswa masing-masing sekolah sampel selanjutnya dibandingkan dan diklasifikasikan. Pengkategorian nilai rata-rata tersebut mengacu pada klasifikasi norma absolut skala 5. Berdasarkan hasil penelitian dapat disimpulkan bahwa penerapan biologi terapan selama ini oleh siswa sekolah menengah pertama di Kabupaten Tabanan masih tergolong cukup. Kondisi ini menuntut kita semua yang bergerak pada sektor pendidikan untuk mencari solusi melalui kajian-kajian lebih lanjut menuju tingkatan yang lebih baik lagi. Dengan demikian, harapannya apa yang telah siswa pelajari dalam bidang biologi mampu berguna bagi mereka dan lingkungannya.
\end{abstract}

KataKunci:Penerapan, Biologi Terapan, Siswa, Sekolah Menengah Pertama, Tabanan

\section{ABSTRACT}

This study aims to determine the application of applied biology in everyday life by junior high school students in Tabanan District of Bali Province. The method used in this research is survey research method. Respondents who are the subject of this research are grade VIII students from 3 sample schools in Tabanan District. The three sample schools are Public Junior High School 2 Tabanan, Public Junior High School 1 Kerambitan, and Public Junior High School 2 Penebel. Data collection was done by distributing questionnaires to respondents. The questionnaire consists of 25 question items. The collected data is analyzed descriptively by presentation in the form of a complete description with visual data in the form of tables and graphs. Each question item is given a range of 0 to 5. The minimum score is 0 , whereas the maximum score is 5. The total score of each student will be converted to a scale of 100. Next is determined the mean-value for each sample school. The mean grade of each 
sample school was then compared and classified. Categorization of the average value refers to the classification of absolute norms scale 5. Based on the results of research can be concluded that the application of applied biology by junior high school students in Tabanan District is still quite enough. This condition requires all of us who are work in the education sector to find solutions through further studies to a better level. Thus, the expectations of what students have learned in the field of biology are useful to them and their environment.

Keywords: Implementation, Applied Biology, Student, Junior High School, Tabanan

\section{PENDAHULUAN}

Ilmupengetahuan yang bermanfaat sangat penting untuk diterapkan. Ilmu pengetahuan yang selama ini kita pelajari, ketahui dan pahami tidak akan memberikan makna yang berarti untuk kesejahteraan umat manusia jika tidak kita terapkan dengan benar. Prinsip inilah yang melatarbelakangi munculnya berbagai macam disiplin ilmu terapan dalam berbagai bidang, salah satunya bidang biologi yang kita kenal dengan istilah biologi terapan (Bigelow \& Bigelow, 2008). Teori, konsep, dan prinsip dalam biologi yang bermanfaat dapat diterapkan dalam berbagai bidang kehidupan sehari-hari di antaranya pertanian, kesehatan, perkebunan, industri, dan masih banyak lagi. Contoh lain penerapan pengetahuan, pemahaman teori, konsep, dan prinsip biologi dalam kehidupan sehari-hari misalnya sikat gigi pada pagi hari dan malam hari menjelang tidur, jenis makanan yang mengandung vitamin tertentu, apa yang boleh dan tidak boleh dimakan dan diminum saat panas dalam, dan masih banyak lagi.

Namun faktanya di lapangan seolah kebalikannya. Berdasarkan pantauan, dan obrolan spontan ringan penulis dengan beberapa anak di warung warga di lingkungan tempat tinggal penulis, ada anak setingkat SMP tidak merasa malu merokok dan mengaku sudah terbiasa merokok. Beberapa anak setingkat SD dan SMP juga terlihat membeli minuman berenergi yang seharusnya bukan untuk mereka. Ketika penulis konfirmasi ke penjual, dikatakan penjual memang banyak anak-anak yang suka membeli minuman berenergi tersebut. Iseng kembali penulis tanya biasanya sikat gigi atau tidak sebelum tidur, 70\% anak-anak tersebut menjawab tidak.

Dari pantauan dan obrolan tersebut, penulis bertanya-tanya dalam hati. Mengapa dari sekian lama belajar ilmu terkait biologi yang bermanfaat, penerapannya belum maksimal?Mengapa dengan bekal ilmu IPA khususnya biologi yang telah mereka pelajari, justru belum mampu membedakan mana yang boleh, mana yang tidak boleh, mana yang berbahaya, dan mana yang tidak berbahaya? Apakah mereka belum paham terkait manfaat penerapan ilmu IPA biologi yang telah meraka pelajari? Sejauh mana mereka menerapkan ilmu terapan biologi yang telah mereka pelajari dalam kehidupan sehari-hari? Apakah mereka tidak diajarkan penerapan dari manfaat ilmu yang mereka pelajari? Apakah mungkin mereka telah paham namun tetap tidak menerapkannya karena factor lain tertentu?

Pertanyaan-pertanyaan inilah yang mengusik hati penulis untuk menemukan jawabannya. Penulis memahami bahwa kemungkinan besar jawaban-jawaban dari pertanyaan tersebut sangatlah komplek. 
Terkait erat dengan berbagai bidang dan faktor. Oleh karena itu, dalam penelitian pendahuluan ini, penulis akanberfokus terlebih dahulu terhadap pertanyaan yaitu bagaimanakah penerapan terkait teori, konsep, dan prinsip biologi terapan yang sangat penting manfaatnya oleh siswa dalam kehidupan mereka sehari-hari.Apakah sudah diterapkan dengan benar atau justru tidak diterapkan sama sekali? Dengan jawaban awal ini nantinya, penulis jadikan acuan dalam mengembangkan penelitian berikutnya untuk menjawab pertanyaan-pertanyaan yang lainnya.

\section{METODE PENELITIAN}

Sebagai penelitian pendahuluan, untuk menjawab pertanyaan yang telah penulis fokuskan di atas, metode yang digunakan dalam penelitian ini adalah metode penelitian survei. Studi survei menanyakan pertanyaan kepada sejumlah besar orang tentang perilaku mereka, sikap mereka, dan opini mereka (Marczyk, DeMatteo, \& Festinger, 2005).

Responden yang menjadi subjek dalam penelitian ini adalah siswa kelas VIII dari 3 sekolah sampel di Kabupaten Tabanan. Adapun ketiga sekolah sampel tersebut adalah SMP Negeri 2 Tabanan, SMP Negeri 1 Kerambitan, SMP Negeri 2 Penebel.

Pengumpulan data dilakukan dengan penyebaran kuesioner kepada responden.Pemilihan kuesioner berdasarkan pertimbangan kesesuaian dengan jenis data yang akan dikumpulkan dan dengan pertimbangan kelebihan yang dimilikinya sebagai berikut. Pertama, dapat mengungkapkan pendapat secara individual maupun kelompok terhadap permasalahan. Kedua, dapat disebarkan untuk responden yang berjumlah besar dalam waktu singkat. Ketiga, biaya lebih murah. Keempat, waktu yang relatif fleksibel sesuai dengan waktu yang telah diberikan peneliti. Kelima, dapat menjaring informasi dalam skala luas dengan waktu yang cepat (Sukardi, 2012).

Kuesioner terdiri dari 25 item pertanyaan. Masing-masing item mengacu pada indikator yang nantinya mampu mengukur sejauh mana penerapan teori, konsep, dan prinsip biologi terapan oleh siswa dalam kehidupan mereka sehari-hari.

Data yang terkumpul dianalisis secara deskriptif. Analisis deskriptif menyajikan data berupa uraian dan penjelasan lengkap, terperinci, yang dilengkapi data visual berupa tabel dan grafik (Bluman, 2008). Masingmasing item pertanyaan diberikan rentangan skor 0 sampai 5. Skor minimal adalah 0, sedangkan skor maksimal adalah 5. Skor total masing-masing siswa nantinya dikonversi kedalam skala 100. Selanjutnya ditentukan nilai-rata-rata untuk masing-masing sekolah sampel. Nilai rata-rata siswa masing-masing sekolah sampel akan dibandingkan dan diklasifikasikan. Pengkategorian nilai ratarata tersebut mengacu pada klasifikasinorma absolut skala 5seperti yang tersaji dalam Tabel 1.

Tabel 1. Klasifikasi Nilai Rata-Rata Siswa

\begin{tabular}{cc}
\hline Nilairata-rata & Kategori \\
\hline $90-100$ & Sangat baik \\
$80-89$ & Baik \\
$70-79$ & Cukup \\
$60-69$ & Kurang \\
$<59$ & Sangat kurang \\
\hline & (Arifin, 2012)
\end{tabular}

\section{HASIL DAN PEMBAHASAN}

Berdasarkan analisis data hasil penelitian yang telah dilakukan, dapat 
dirangkum nilai rata-rata siswa masingmasing sekolah sampel sesuai dengan yang tersaji dalam Tabel 2.

Tabel 2. Nilai Rata-Rata Penerapan Biologi Terapan Siswa Sekolah Sampel.

\begin{tabular}{lll}
\hline \multicolumn{1}{c}{ Sekolah Sampel } & \multicolumn{1}{c}{ Nilai } \\
rata- rata & Kategori \\
\hline SMP N 2 Penebel & 76.87 & Cukup \\
SMP N 1 Kerambitan & 67.96 & Kurang \\
SMP N 2 Tabanan & 79.49 & Cukup \\
Total rata-rata & 74.78 & Cukup \\
\hline
\end{tabular}

Jika kita bandingkan nilai rata-rata ketiga sekolah sampel tersebut ke dalam sebuah grafik, maka akan terlihat seperti Gambar 1.

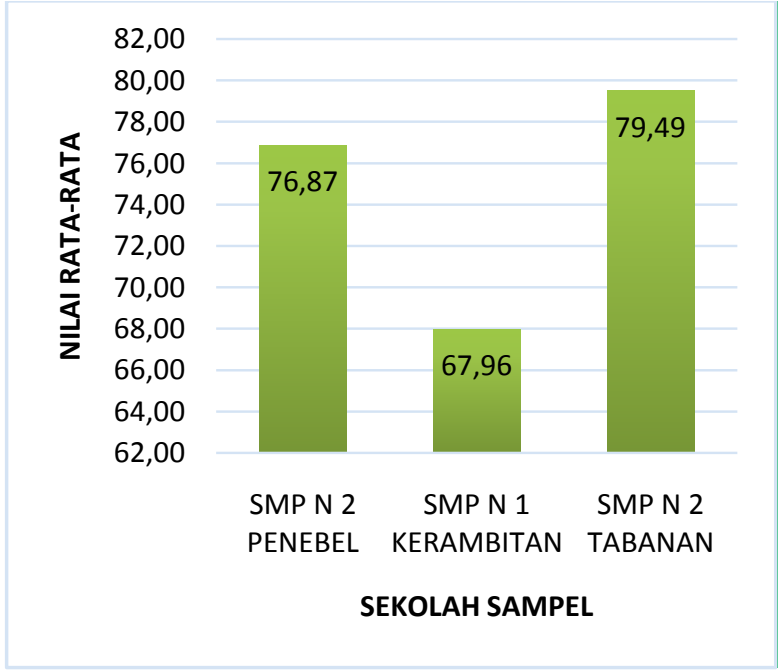

Gambar 1. Grafik Perbandingan NilaiRata-Rata Sekolah Sampel.

Sebelum membahas temuan hasil penelitian, penulis terlebih dahulu menjelaskan terkait subjek yaitu responden dan sekolah yang dijadikan sampel penelitian. Pemilihan responden siswa sekolah menengah pertama berdasarkan pertimbangan yang penulis lakukan di antaranya sebagai berikut. Pertama, kesesuaian dengan pengamatan dan hasil obrolan spontan di lapangan sebagian besar dengan anak-anak pada tingkat sekolah menengah pertama. Kedua, untuk mengetahui data pada tahap yang lebih awal. Jika hasilnya kurang baik, maka lebih awal dapat dilakukan perubahan menuju hasil yang lebih baik. Di lain pihak, pemilihan ketiga sekolah sampel dimaksudkan untuk menambah variasi data dari 3 zona wilayah di daerah Kabupaten Tabanan Bali yaitu zona pusat kota, zona pinggiran kota dan pedesaan. Sehingga seluruh zona wilayah Kabupaten Tabanan terwakili.

Berdasarkan sajian data penelitian sebelumnya pada Tabel 2 dan Gambar 1, dapat kita lihat nilai total nilai rata-rata penerapan biologi terapan siswa sebesar 74.78 yang masuk ke dalam kategori cukup. Kalau kita lebih rinci terhadap masing-masing sekolah sampel, dua sekolah sampel memperoleh nilai rata-rata dengan kategori cukup dan sisanya lagi satu sekolah sampel memperoleh nilai rata-rata yang masuk ke dalam kategori kurang. Data tersebut juga menunjukkan bahwa ketiga zona wilayah sekolah sampel yaitu perkotaan, pinggiran kota, dan pedesaan tidak menunjukkan perbedaan yang signifikan.

Informasi dari hasil penelitian yang terangkum, ternyata dalam skala yang lebih luas bersesuaian dengan hasil pantauan dan obrolan penulis sebelumnya. Ini artinya, penerapan dengan benar terkait teori, konsep, prinsip dari biologi terapan yang dilakukan siswa selama ini masih perlu ditingkatkan. Temuan ini memang sedikit mengecewakan bagi penulis. Ilmu yang selama ini dipelajari dengan berbagai model kurikulum, model pembelajaran inovatif, berbagai variasi 
metode dan strategi pembelajaran, serta teknik penilaian terkini, nyatanya belum mampu secara maksimal mengantarkan siswa menerapkannya dengan benar paling tidak dalam kehidupan mereka sehari-hari. Ini artinya nilai kebermaknaan ilmu yang mereka pelajari, belum memberikan manfaat yang maksimal. Kondisi ini harus segera ditindaklanjuti dengan solusi-solusi yang tepat. Untuk menemukan solusi yang tepat, diperlukan penelitian-penelitian lanjutan. Jangan sampai ilmu yang telah dijejalkan selama ini kepada siswa hanya digunakan untuk persiapan ujian semata, setelah itu terlupakan tanpa makna berarti.

Tidak banyak penelitian Pendidikan yang mengkaji penerapan IPA atau biologi dalam kehidupan sehari-hari. Penelitianpenelitian Pendidikan IPA dan biologi selama ini sebagai besar mengkaji terkait model pembelajaran yang tepat, metode pembelajaran, strategi pembelajaran, evaluasi pembelajaran, dan sejenisnya. Kondisi tersebut kemungkinan menyebabkan kurang tersentuhnya kegiatan pembelajaran yang memfasilitasi pengetahuan, pemahaman dan kesadaran siswa dalam menerapkan ilmu yang telah mereka pelajari. Namun demikian, terdapat beberapa buku yang dapat dijadikan acuan untuk memfasilitasi siswa mampu menerapkan apa yang telah mereka pelajari dari pelajaran IPA dan biologi. Sehingga mereka akan mampu mengambil keputusan dalam kehidupan mereka sehari-hari terkait mana yang benar, mana yang boleh dan tidak boleh, mana yang sehat dan tidak sehat, dan sebagainya.

Dalam bukunya(Bigelow \& Bigelow, 2008)dijelaskan definisi, jenis, dan tahapantahapan rinci yang dapat dilakukan untuk mengantarkan siswa mengaplikasikan ilmu yan telah mereka pelajari dengan benar mulai dari lingkungan sekolah sampai rumah masing-masing. Dalam buku yang lain(Cedar, 2012)menjabarkan penerapan ilmu biologi dalam bidang kesehatan. Penerapan Ini penting bagi siswa karena berdampak langsung pada dirinya. Dengan demikian, ilmu yang mereka peroleh secara langsung berguna dalam pengambilan keputusan dalam mempertahankan dan menjaga diri mereka tetap sehat.

\section{SIMPULAN}

Berdasarkan uraian hasilpenelitiandan pembahasan sebelumnya,dapat disimpulkan bahwa penerapan biologi terapan selama ini oleh siswa sekolah menengah pertama di Kabupaten Tabanan masih tergolong cukup. Kondisi ini menuntut kita semua yang bergerak pada sektor pendidikan untuk mencari solusi melalui kajian-kajian lebih lanjut menuju tingkatan yang lebih baik lagi. Dengan demikian, harapannya apa yang telah siswa pelajari dalam bidang biologi mampu berguna bagi mereka dan lingkungannya.

\section{DAFTARPUSTAKA}

Arifin, Z. (2012). Evaluasi Pembelajaran. Bandung: PT. Remaja Rosdakarya.

Bigelow, M. A., \& Bigelow, A. N. (2008). Applied Biology : An Elementary Textbook and Laboratory Guide (1911). United states: Kessinger Publishing.

Bluman, A. G. (2008). Elementary Statistics: A Step by Step Approach, 7th Edition. New York: McGraw-Hill .

Cedar, S. H. (2012). Biology for Health: Applying the Activities of Daily Living. London: Palgrave Macmillan. 
Marczyk, G., DeMatteo, D., \& Festinger, D. (2005). Essentials of Research Design and Methodology. New Jersey: John Wiley \& Sons, Inc.

Sukardi. (2012). Metodologi Penelitian Pendidikan. Jakarta: Bumi Aksara. 